JURNAL ILMIAH ELEKTRONIKA DAN KOMPUTER, Vol.13, No.1, Juli 2020, pp. 151 - 158

p-ISSN : $1907-0012$ (print)

e-ISSN : 2714-5417 (online)

http://journal.stekom.ac.id/index.php/elkom

- page 151

\title{
Safety Stock Information Dashboard of Hospital Pharmaceutical Inventory in Integration with Indonesia National Health Insurance
}

\author{
${ }^{1}$ Priyo Nugroho Adi, * ${ }^{2}$ Susana Ayu Handayani, ${ }^{3}$ Toni Prahasto \\ ${ }^{1}$ Institut Teknologi dan Bisnis Semarang; priyo.adi.edu@itbsemarang.ac.id \\ ${ }^{2}$ Universitas Stikubank; susanaayuhandayani@mhs.unisbank.ac.id \\ ${ }^{3}$ Universitas Diponegoro; toniprahasto@lecturer.undip.ac.id
}

\section{ARTICLE INFO}

Article history:

Received 30 April 2020

Received in revised form 2 Mei 2020

Accepted 10 Juni 2020

Available online Juli 2020

\begin{abstract}
In all section of inventory management, including inventory management in a hospital, minimize cost and ideal inventory accommodation against demand has always been a primary goal (Varghese, 2012). Nearly a third of the operational success of a hospital is in the field of medical supplies. In its usual way, inventory management in hospitals using the approach to the demand usage, the characteristics of the item and the estimate of the demand. The model presented in this study accommodates that common approach which use a combination of inventory safety stock limit, Economic Order Quantity, and reorder point in a information system dashboard that capable to provide quick and easy information about the condition of inventory management. The result of the system are used for the hospital pharmaceutical inventory management in integration with the INACBGs to optimize the inventory performance.
\end{abstract}

Key Words: optimize, the inventory, performance.

\begin{abstract}
Abstrak
Dalam semua bidang manajemen persediaan, termasuk manajemen persediaan dalam rumah sakit, meminimalisir biaya dan akomodasi yang ideal atas permintaan selalu menjadi tujuan yang utama (Varghese, 2012). Hampir sepertiga keberhasilan operasional sebuah rumah sakit ada pada bidang persediaan medis. Pada umumnya, manajemen persediaan dalam rumah sakit menggunakan pendekatan kepada penggunaan persediaan, karakteristik dari persediaan serta pendugaan terhadap permintaan. Model yang dipresentasikan dalam penelitian ini mengakomodasi pendekatan umum tersebut dengan menggunakan kombinasi dari batas aman persediaan, Economic Order Quantity, dan titik balik pemesanan dalam sebuah dashboard sistem informasi yang mampu menyediakan informasi yang cepat
\end{abstract}

Received April 30, 2020; Revised Mei 2, 2020; Accepted Juni 22, 2020 
dan mudah tentang kondisi persediaan. Hasil dari sistem digunakan untuk pengelolaan persediaan farmasi rumah sakit yang terintegrasi dengan INACBGs untuk mengoptimalkan kinerja persediaan sediaan farmasi.

Keywords : medical inventory; information system dashboard

\section{PENDAHULUAN}

Perencanaan dan pengendalian batas aman persediaan dalam manajemen inventori merupakan hal krusial untuk menentukan performa bisnis. Penanaman dana yang terlalu besar untuk persediaan dapat menyebabkan biaya penyimpanan menjadi berlebih. Sedangkan apabila persediaan tidak mencukupi, kekurangan persediaan dapat menyebabkan penambahan biaya untuk menanggulanginya. Keterlambatan pemenuhan pesanan juga mengurangi kualitas dan kredibilitas pemasok pesanan (Gonzales, 2010). Dalam bidang farmasi, perhitungan persediaan obat bukan merupakan hal yang mudah karena berkaitan dengan kondisi lingkungan yang sangat sulit diperhitungkan, seperti : epidemi penyakit, loyalitas dokter terhadap merk tertentu, lokasi supplier farmasi dan yang lainnya. Keterlambatan atas permintaan berkaitan dengan kesehatan bahkan nyawa seseorang terkadang tidak dapat ditoleransi.

Dari kondisi yang telah disebutkan dalam penelitian ini dibangun model yang memiliki kemungkinan untuk menjadi sistem pendukung keputusan pengelolaan batas aman persediaan farmasi. Model tersebut memiliki antarmuka dashboard sistem informasi yang memungkinkan informasi pendukung keputusan dapat disampaikan dengan mudah dalam waktu yang singkat. Dan penangkapan informasi dalam waktu yang singkat inilah yang diharapkan dapat memberi dampak yang baik dalam pengambilan keputusan.

Demikian penelitian ini bertujuan untuk merancang dan membangun model prototipe batas aman persediaan khususnya dalam hal kefarmasian dengan antarmuka dashboard yang mampu memberikan informasi pendukung keputusan pengendalian persediaan.

\section{Kerangka Teori}

\subsection{Dasar Teori Inventory}

Batas aman persediaan sudah menjadi permasalahan periodik untuk masing-masing pengelola persediaan (Inderfurth K, 2013). Masing-masing bidang persediaan memiliki tantangan unik dan kompleks untuk dapat melakukan determinasi terhadap batas persediaan aman (Inderfurth K, 1998). Sejatinya batas aman persediaan baku adalah hasil dari waktu tunggu pemesanan (dalam hari) dan angka permintaan (Zipkin, 2000). Namun bila memperhatikan fluktuasi permintaan yang sukar diduga, yang mempengaruhi perhitungan batas aman adalah Tingkat Layanan (Service Level), Lead Time, dan fluktuasi permintaan (King, 2011). Untuk mengantisipasi permintaan yang hampir mustahil untuk konstan, perhitungan batas aman persediaan ada penambahan perhitungan sebagai berikut :

$$
S S=Z \times L T \times D
$$

Dimana :

SS $\quad=$ Batas Aman Persediaan (Safety Stock Limit)

$\mathrm{Z} \quad=$ Pengali dari Tingkat Layanan (Service Level)

LT $\quad=$ Lead Time

$\mathrm{D} \quad=$ Demand (Permintaan)

Dari perhitungan di atas, hanya $\mathrm{Z}$ yang dapat ditentukan sedangkan Lead Time dan demand (permintaan) hanya dapat dihitung, dideterminasi atau diperkirakan. Pengali dari tingkat layanan inilah yang ditentukan sebagaimana komitmen penyediaan dari pengelola persediaan.

JURNAL ILMIAH ELEKTRONIKA DAN KOMPUTER, Vol.13, No.1, Juli 2020, pp. 151-158 
p-ISSN : 1907-0012 (print); e-ISSN : $2714-5417$ (online)

Di sisi lain, pengelolaan inventori yang optimal adalah pengelolaan inventori yang meminimalkan angka batas persediaan aman secara signifikan (Persona, 2007). Kekuatan rantai pasokan juga menjadi salah satu faktor yang akan mengoptimalkan batas aman persediaan (Inderfurth K, 2013).

\subsection{Tinjauan Pustaka}

Dalam bidang pengelolaan persediaan sebuah rumah sakit biaya persediaan yang minimal dan akomodasi yang ideal terhadap permintaan selalu menjadi tujuan yang utama (Varghese, 2012). Manajemen persediaan yang baik mampu memaksimalkan setiap potensial penghematan biaya persediaan dan menduga fluktuasi permintaan terhadap persediaan yang dikelola. Rumah sakit umum biasanya menghabiskan $25 \%$ sampai $30 \%$ dari budgetnya untuk persediaan medis beserta pengelolaanya (Varghese, 2012). Ini berarti hampir dari sepertiga keberhasilan operasional sebuah rumah sakit ada pada bidang persediaan medis. Dalam data penelitian rumah sakit di Amerika tahun 2009 , pengecer persediaan yang menuai sukses besar adalah pengecer persediaan yang mampu melakukan kontrol terhadap biaya persediaan dan memiliki kapasitas persediaan yang fleksibel yang mampu menyesuaikan kondisi permintaan. Dari dua penelitian yang mendahului , dapat disimpulkan bahwa sepertiga keberhasilan operasional rumah sakit ditentukan dari keberhasilan implementasi pengelolaan persediaan.

Pada umumnya ada 3 (tiga) pendekatan yang digunakan dalam pengelolaan persediaan dalam rumah sakit. Yang pertama adalah pendekatan terhadap penggunaan persediaan. Dari data hasil survey tahun 2012 terhadap rumah sakit, terungkap umumnya dari 20\% dari persediaan mengakomodasi $80 \%$ dari seluruh permintaan. Hal ini berarti hanya $20 \%$ item dalam persediaan yang benar-benar krusial dalam persediaan. Jadi target dari pendekatan yang pertama ini adalah mengidentifikasi $20 \%$ item terpenting dari valuasi permintaannya.

Pendekatan yang kedua adalah pendekatan terhadap karakteristik dari item persediaan yang dikelola rumah sakit. Ada karakteristik dari persediaan yang bisa dipelajari dari pengelolaan persediaan di rumah sakit. Contohnya seperti obat-obat subtitusi. Seperti obat penghilang nyeri yang dapat menggunakan obat yang berbeda namun memiliki khasiat yang sama. Pemindaian terhadap karakteristik dari persediaan ini sejatinya dapat meningkatkan efisiensi dari pengelolaan persediaan. Obat yang masuk dalam persediaan adalah obat yang masuk dalam kualifikasi terbaik menurut karakteristik permintaan dan persediaan. Hal ini akan meminimalisir jumlah persediaan yang harus dikelola. Dengan berkurangnya jumlah persediaan yang harus dikelola, biaya persediaan juga dapat lebih efisien.

Yang ketiga, pendekatan yang digunakan untuk mengelola persediaan adalah pendekatan yang melakukan pendugaan maupun peramalan dari permintaan yang akan datang terhadap persediaan. Dalam pendekatan yang ketiga ini ada banyak metode peramalan permintaan yang digunakan. beberapa contoh metode yang umum digunakan meliputi sejarah permintaan, metode linier, metode fuzzy serta metode berbasis trend. Namun yang paling populer dalam rumah sakit adalah metode peramalan atau pendugaan yang berdasar dari sejarah permintaan dalam rumah sakit tersebut. Hal tersebut berkaitan erat dengan dokter utama dalam rumah sakit, spesialisasi rumah sakit dan musim maupun wabah penyakit yang menyerang daerah operasional rumah sakit tersebut. Jadi dalam rumah sakit belum tentu pola pengelolaan persediaan rumah sakit dapat langsung diterapkan pada rumah sakit yang lain.

\section{Metodologi}

Dari tiga pendekatan umum yang berlangsung dalam sebuah manajemen persediaan dalam rumah sakit, penelitian ini menyusun skema model yang mempermudah pengguna dari model untuk menerima informasi berdasarkan dari sejarah data yang telah dilampaui. Dibawah ini adalah skema masukan, proses, dan keluaran dari model tersebut. 


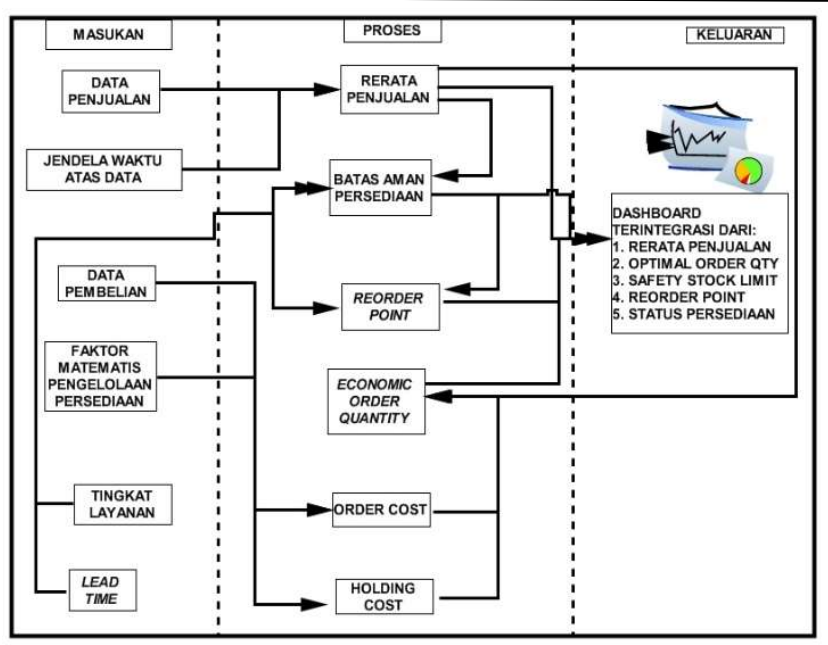

Gambar 1. Skema dari Prototipe Model

Dalam prototipe model yang dibangun, terdapat 7 (tujuh) interaksi aktor dengan sistem dilakukan dalam model yang dibangun. Sedangkan 1 (satu) interaksi yaitu impor data dilakukan dalam akomodasi default dari alat penelitian yaitu Apache Web Server. Dalam prototipe model batas aman persediaan 7 interaksi aktor dengan sistem diimplementasikan secara fungsional dalam antarmuka berbasis grafis. Dibawah ini adalah gambar dari Use Case Diagram dari prototipe yang dibangun.

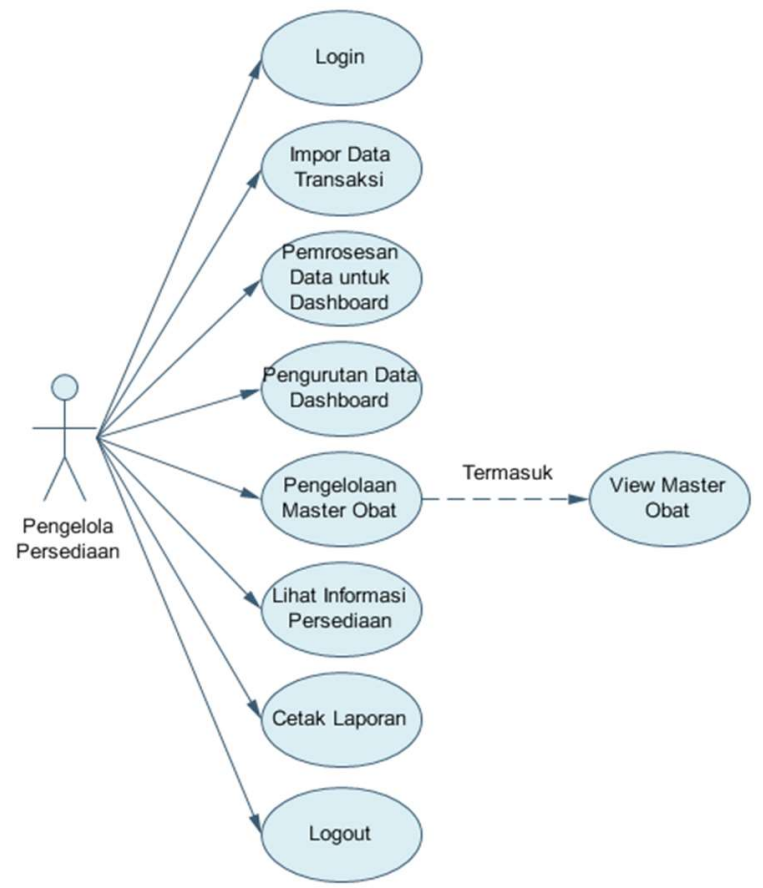

Gambar 2. Use Case Diagram dari Prototipe Model

Interaksi login digunakan untuk melakukan validasi terhadap hak akses pengguna. Pemrosesan dashboard data digunakan untuk memproses data yang akan dijadikan bahan perhitungan untuk menghasilkan informasi dalam dashboard. Pengurutan data dashboard digunakan untuk mengurutkan record data berdasarkan kendali pengelola persediaan. 
p-ISSN : 1907-0012 (print); e-ISSN : $2714-5417$ (online)

Hal ini memungkinkan pengelola persediaan melakukan pendekatan manajemen persediaan selain dari saran pengelolaan yang diberikan oleh prototipe model. Pengelolaan master obat berfungsi untuk melakukan pengolahan data terhadap master obat. Pengolahan yang dimaksud adalah penambahan, pembaruan maupun penonaktifan. Dalam master obat ini juga segmentasi obat terbagi-bagi sesuai dengan karakteristiknya.

Fungsi informasi persediaan diakomodasi oleh dashboard yang memberikan warna-warna yang saling berbeda sesuai dengan kondisi pengelolaan persediaan. Warna hijau untuk mewakili kondisi ideal dari persediaan. Warna kuning mewakili kondisi siaga, pemesanan persediaan harus segera dilakukan. Warna merah mewakili kondisi darurat dari persediaan, pemesanan tidak dapat ditunda lagi. Warna oranye mewakili penumpukan persediaan, harus segera dilakukan evaluasi maupun pengelolaan yang dapat mengurangi persediaan. Sedangkan warna abu-abu dan putih merupakan kondisi permintaan persediaan yang terlalu sedikit.

Fungsi cetak laporan memungkinkan pengelola persediaan menyimpan dan mencetak data hasil pengolahan menurut rekam waktu serta variabel pengelolaan tertentu. Data hasil pengolahan ini berupa data berformat excel yang mengalami proses konversi dari data yang ada pada tabulasi sistem. Fungsi logout bekerja untuk menghapus sesi pengguna yang berhak mengakses sistem sehingga tidak disalahgunakan. Selain berfungsi untuk meningkatkan keamanan sistem, fungsi logout ini akan menutup koneksi-koneksi serta sesi yang digunakan oleh pengguna sehingga meningkatkan efisiensi penggunaan memori dalam sistem. Sedangkan interaksi untuk melakukan impor data dilakukan antara pengguna dengan webserver bawaan yaitu apache.

Dalam proses utamanya, prototipe model akan melakukan proses untuk melakukan generasi data yang akan digunakan sebagai dasar dari sistem untuk menyajikan informasi yang berupa dashboard. Dibawah ini adalah activity diagram yang menjelaskan runtutan proses generasi data terjadi.

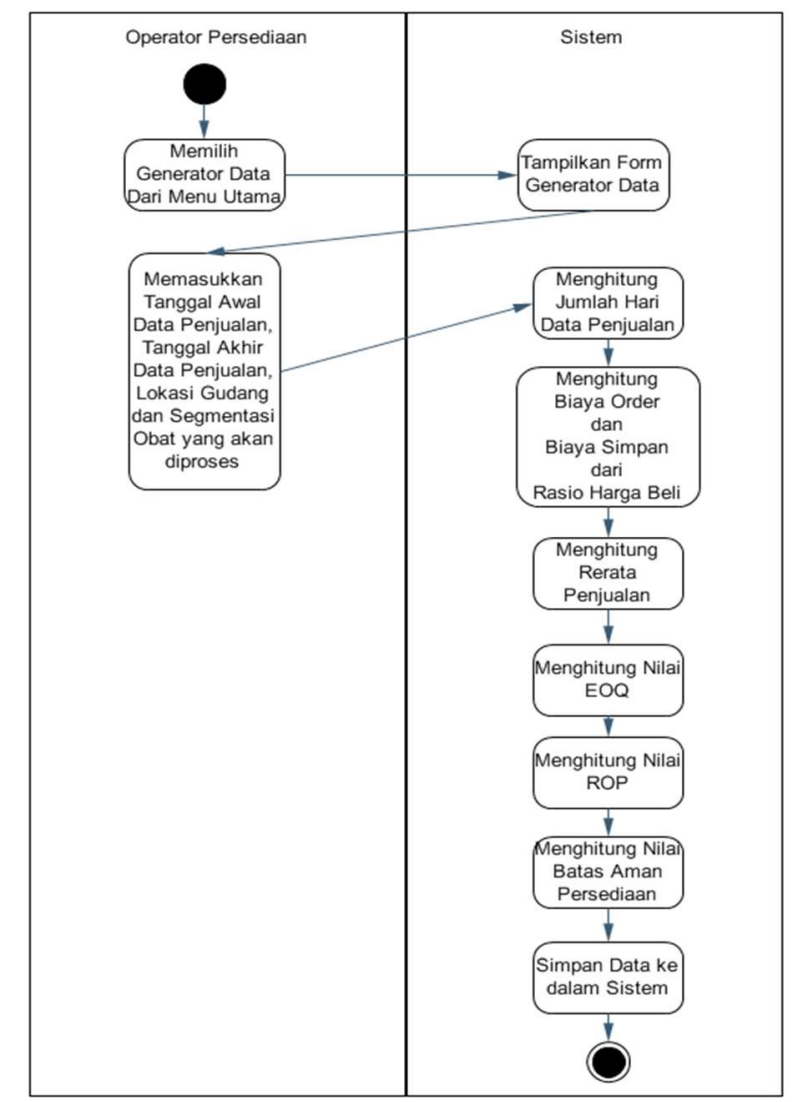

Gambar 3. Activity Diagram Proses Generasi Data 


\section{Hasil dan Pembahasan}

Setelah prototipe model selesai dibangun dan diuji, prototipe model mampu mengimplementasikan kebijakan umum pengelolaan persediaan rumah sakit dalam sebuah model yang lebih ringkas dan informatif. Kebijakan pertama yang menggunakan pendekatan tingkat permintaan dapat dilihat dengan mudah dengan fungsi pengurutan batas aman. Batas aman yang semakin tinggi menandakan jumlah permintaan yang tinggi begitu pula sebaliknya. Kebijakan yang kedua yang menggunakan pendekatan terhadap karakteristik persediaan diakomodasi oleh pembagian segmentasi persediaan dalam pengelolaan data. Diharapkan dengan segmentasi ini, pengelola persediaan dapat lebih selektif untuk mengaktifkan persediaan yang sesuai dengan karakteristik yang dirumuskan dalam kebijakan manajemen persediaan tiap-tiap rumah sakit. Kebijakan ketiga yang merupakan pendugaan terhadap performa pengelolaan persediaan diakomodasi oleh sistem dengan memberikan informasi mengenai situasi persediaan yang ada yang dihasilkan dari perbandingan kondisi persediaan yang ada dengan variabel-variabel yang diputuskan menjadi faktor-faktor penentu dalam manajemen pengelolaan persediaan.

Dari prototipe model yang dibangun, peneliti menemukan bahwa dalam pengelolaan persediaan farmasi memiliki perbedaan yang cukup mendasar dibanding pengelolaan persediaan yang lain. Kebijakan yang diterapkan oleh rumah sakit adalah kebijakan yang berupa konsep umum persediaan untuk mengelola persediaan rumah sakit. Namun untuk detail dari praktek kebijakan pengelolaan di dalamnya sangat bergantung dari karakteristik dari setiap rumah sakit. Beberapa faktor yangg mempengaruhi penerapannya ialah : pilihan dokter terhadap perbekalan tertentu, spesialisasi rumah sakit, cakupan kawasan pelayanan rumah sakit dan $\mathrm{MoU}$ antara rumah sakit dengan masing-masing pemasok persediaan. Dengan demikian keberhasilan pengelolaan persediaan dalam rumah sakit sebagian besar bukan ditentukan oleh kebijakan melainkan kecepatan penyampaian informasi pengelolaan persediaan kepada pihak yang berhak untuk memutuskan kebijakan pengelolaan persediaan. Hasil dari model yang berupa informasi yang disajikan dalam sebuah dashboard dapat dilihat di bawah ini.

\section{DASHBOARD BATAS AMAN PERSEDIAAN}

FusionCharts Trial

\section{DIAGRAM PERSEDIAAN}

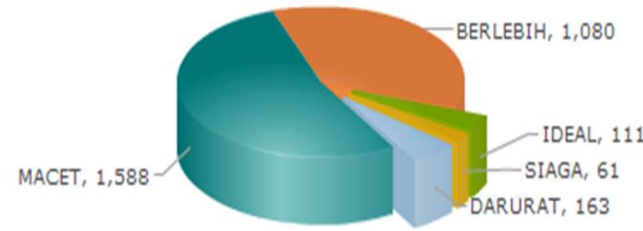

Gambar 4. Potongan Tampilan dari dashboard sistem

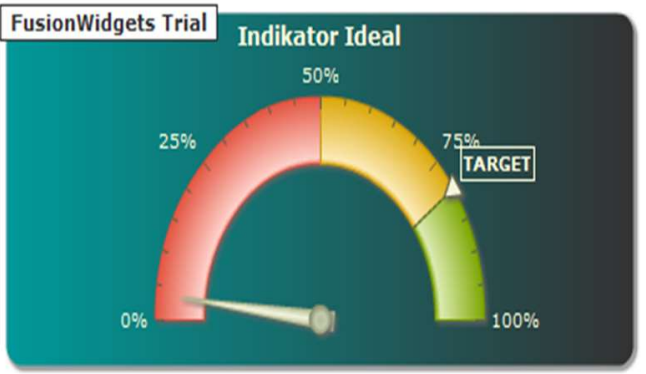

JURNAL ILMIAH ELEKTRONIKA DAN KOMPUTER, Vol.13, No.1, Juli 2020, pp. 151-158 
Gambar 5. Angular Display dari dashboard sistem

\section{Kesimpulan}

Prototipe model batas aman persediaan ini menyediakan informasi berkenaan dengan pengelolaan persediaan yang cepat dan mudah dipahami oleh pengguna sistem. Informasi yang dapat diketahui dari model adalah rerata permintaan, nilai balik pemesanan, Economic Order Quantity, dan nilai persediaan yang ada dalam suatu periode. Hal ini akan membantu pengguna sistem untuk dapat mengetahui informasi kebutuhan guna menunjang keputusan mengenai persediaan. Informasi yang dihasilkan oleh sistem juga dapat digunakan untuk merencanakan dan mengendalikan batas aman persediaan khususnya dalam hal kefarmasian. Pengelompokan warna yang tersaji dalam dashboard diharapkan memudahkan para pengguna dalam mengetahui kondisi persediaan secara lebih cepat. Beberapa hal yang dipermudah dengan model ini adalah :

a. perhitungan variabel penentu batas aman persediaan

b. akses informasi batas aman persediaan

c. penangkapan informasi pendukung keputusan pengendalian persediaan

Sistem komunikasi visual dari prototipe model ini disarankan untuk diintegrasikan dengan sistem operasional pengelolaan persediaan karena mempermudah pengambilan keputusan persediaan operasional dalam pengelolaan persediaan rumah sakit. Metode dalam prototipe model ini juga masih memungkinkan diperlengkapi dengan metode-metode pendugaan pengelolaan persediaan yang non konvensional dan multi policy seperti JustInTime, berbagai kombinasi logika fuzzy dan pendugaan dengan metode non linier yang lain. Prototipe model sistem ini juga masih memungkinkan untuk ditambah dengan pengelolaan padanan obat, mengingat beberapa obat memiliki khasiat yang sama. Hal ini akan lebih meningkatkan efektivitas dalam pengelolaan persediaan farmasi yang lebih sesuai dengan standar INA CBGs .

\section{Daftar Pustaka}

Aryal, S, P., 2013, Being Effective and Efficient Manager, India Mobile Telecommunication Publication, 18-21

Baronchelli, A., et all, 2004, Dictionary-based method form information extraction, Physica A 342, 294-300

Chen, Fangruo, 1998, Echelon Reorder Point, Installation Reorder Point, The Value of Centralized Demand Information, Management Science 44, 221

Chung, K., dan Cardenas L.E., 2012, The complete solution procedure for the EOQ and EPQ inventory models with linear and fixed backorder costs, Mathematical and Computer Modelling 55, 21512156

Dionyssopoulou, P, et all, 2013, Visual Communication Management Technologies in Promoting Tourism Destinations, International Journal of Management Technology, 1-16

Gaedke, M., et all, 2000, Integrating Web-based E-Commerce Application with Bussiness Application Systems, Netnomic Journal 2, 117-138

Hedley Y., et all, 2006, Sampling, Information Extraction and Summarisation of Hidden Web Database, Int. Journal of Data and Knowledge Engineering 59, 213-230

Hinum, Klaus., 2004, Human Centred Design for Graphical User Interface, Vienna University of Technology, 5-144

Hojati, M., 2004, Bridging the gap between probabilistic and fuzzy-parameter EOQ model, Int. J. Production Economic 91, 215-221

Inderfurth, K., dan Minner, S., 1998, Safety stock in multi-stage inventory system under different service measures, European Journal of Operational Research 106, 57-73

Inderfurth, K., dan Vogelgesang, S., 2013, Concepts for safety stock determination under stochastic demand and different types of random production yield, European Journal of Operational Research 224, 293-301

Safety Stock Information Dashboard of Hospital Pharmaceutical Inventory in Integration with Indonesia National Health Insurance 
Min, W., dan Pheng, L.S., 2006, EOQ, JIT and fixed costs in the ready-mixed concrete industry, Int. J. Production Economics 102, 167-180

Mishra, S.S., dan Mishra, P.P., 2008, Price determination for an EOQ model for deteriorating items under perfect competition, Computer and Mathematics with Application 56, 1082-1101

Mykowecka, A., et all, 2008, Rule-based information extraction from patients clinical data, Journal of Biomedical Informatics 42, 923-936

Persona, A., et all, 2007, Optimal safety stock levels of subassemblies and manufacturing components, Int. J. Production Economics 110, 147-159

Varghese, Vijith., et all, 2012, Applying Actual Usage Inventory Management Best Practice in a Health Care Management, Int. J. Supply Chain Management, 1-10

Wee, L.K.A., et all, 1999, A generic Information extraction architecture for financial application, Expert System with Application 16, 343-356

Welsch,N., Liebmann, Clauss., 2003, Farben, Natur Technik Kunst, Spektrum Akademicher Verlag

\section{Buku :}

Few, S, 2006 Information Dashboard Design, O'Reilly Publication

F.W. Harris, 1913, How Many Part Make At Once, The Magazine of Manegement 10, 135-152

Jacobs F., R., et all 2011, Manufacturing Planning and Control for Supply Chain Management, McGraw Hill

King, Peter, 2011, understanding Safety Stock and Mastering its Equations, APICS Magazine, 33-36

Meier, J, Barbara., 1988, ACE: A Colour Expert System for User Interface Design, ACM Publication, $117-128$

Zipkin, P., H., 2000, Foundations in Inventory Management, McGraw Hill

\section{Skripsi/tesis/disertasi:}

Gonzales, J., Gonzales, D., 2010, Analysis of an Economic Order Quantity and Reorder Point Inventory Control Model for Company, California Polytechnic State University, 3-27 